(C) 2018

Жуков О. В., доктор біологічних наук

Дніпровський національний університет імені Олеся Гончара

Пономаренко С. В., здобувач

Полтавська державна аграрна академія

\title{
ПРОСТОРОВО-ЧАСОВА ДИНАМІКА УРОЖАЙНОСТІ ЗЕРНОВИХ ТА ЗЕРНОБОБОВИХ КУЛЬТУР У ПОЛТАВСЬКІЙ ОБЛАСТІ
}

\section{Рецензент - доктор сільськогосподарських наук, професор П. В. Писаренко}

\begin{abstract}
У роботі розроблено методичні підходи для виокремлення характеру дї на урожайність на регіональному масштабі факторів агроекологічної, агротехнологічної та агроекономічної природи. Показано, ш⿻ урожайність культур зернових та зернобобових у сільськогосподарських підприємствах Полтавської області по районах у середньому за

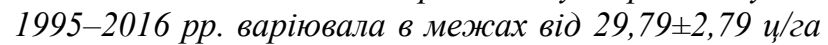

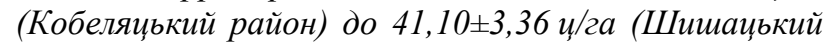
район). Найменший рівень варіювання показників врожайності культур зернових та зернобобових за період дослідження був характерний для Оржицького району (коефіиієнт варіації (CV) 27,95\%), a найбільший - для Чорнуханського $(\mathrm{CV}=62,02 \%)$. Просторова компонента варіювання середнього рівня врожайності зернових та зернобобових культур незначна. Встановлено суттєвий внесок факторів просторової природи у варіювання мінливості врожайності сільськогосподарських культур. Встановлено чіткий тренд збільшення врожайності зернових та зернобобових за період дослідження, який може бути описаний лінійною залежністю. Коефіиієнти лінійної моделі змістовно інтерпретовані як швидкість зростання урожайності з часом та потениіал урожайності y початковий період дослідження.
\end{abstract}

Ключові слова: динаміка урожайності, тренд, часові ряди, просторова варіабельність, агроекологічні фактори.

Постановка проблеми. Динаміка урожайності сільськогосподарських культур визначається як результат сукупної дії агроекологічних, агроекономічних та агротехнологічних чинників. У контексті агроекономічних чинників слід вказати на соціально-економічну кризу в Україні на початку 90-х років ХХ століття. При переході до ринкових відносин для всіх галузей економіки було створено умови вільного ціноутворення, а для сільського господарства запроваджено орієнтовні ціни, які зростали значно нижчими темпами, ніж на товари і послуги, які споживаються сільським господарством, що спричинило диспаритет цін не на користь аграріїв. Це, в свою чергу, вплинуло як на розвиток сільського гос- подарства в цілому, так і на виробництво зерна [6]. Серед агроекологічних чинників важливе значення мають глобальні зміни клімату [11]. Це зумовлює необхідність адаптації вітчизняного сільського господарства до таких змін шляхом розробки нових наукових підходів та економічного обгрунтування технологій вирощування певних зернових культур, які користуються попитом на внутрішньому та світовому ринках [2]. Продуктивність рослин, яка безпосередньо впливає на формування економічних показників зерновиробництва, також залежить від певних грунтово-кліматичних умов [1]. Тому аналіз просторово-часової динаміки урожайності зернових та зернобобових культур в Полтавській області та визначення факторів, які на неї впливають, $\epsilon$ важливою науковою проблемою.

Аналіз основних досліджень і публікацій, у яких започатковано розв'язання проблеми. Агротехнологічні чинники є функцією агроекономічних. Встановлено пряму залежність урожайності зернових культур від своєчасного i ефективного проведення будь-якого агротехнологічного прийому. Всі прийоми важливі, особливо сівба в кращі агрономічні строки. До строків сівби підключається сортовий і насіннєвий фактор, ефективні сівозміни, норми внесення мінеральних і органічних добрив, способи захисту рослин від бур'янів, хвороб і шкідників, забезпечення технічними засобами тощо. Всі ланки технологічного ланцюга повинні бути тісно взаємопов'язані [3]. Основними напрямами підвищення адаптованості виробництва зернових культур в сучасних умовах $є$ : розміщення посівів сільськогосподарських культур в сприятливих грунтово-кліматичних умовах, створення адаптованих сортів і гібридів до природних умов України, переведення зернової галузі на постіндустріальні моделі розвитку, забезпечення сировинної бази для розвитку біоенергетики, створення кормової бази для тваринництва, розвиток органічного виробництва, структуризація зернового ринку [6]. 


\section{СІЛЬСЬКЕ ГОСПОДАРСТВО. РОСЛИННИЦТВО}

Загальний рівень урожайності зернових та зернобобових культур та ступінь варіювання цього показника залежить від агроекономічних (у широкому розумінні цього поняття) та агроекологічних чинників [12]. Вплив цих чинників підкоряється принципу лімітуючого фактору: визначальним $\epsilon$ той фактор, який знаходиться у недостатку (або надлишку). Для дослідження динаміки врожайності круп'яних культур використано кореляційно-регресійне моделювання [12]. Для описання тренду динаміки урожайності зернових та зернобобових культур в Україні за період 1913-2012 застосовано поліноміальну модель четвертого порядку [6].

Застосування постіндустріальних моделей розвитку зернової галузі передбачає розробку i впровадження ресурсозберігаючих біоадаптивних технологій вирощування сільськогосподарських культур, інтегрованої системи захисту рослин, методів оптимізації процесів росту і розвитку рослин з урахуванням змін клімату та на основі принципів точного землеробства [6].

Просторове варіювання агроекономічних та агроекологічних чинників має різний характер [10]. Важливим аспектом варіювання також $€$ закономірні патерни динаміки врожайності у часі. Тому дослідження закономірностей варіювання врожайності в просторі та часі може надати підтвердження тій або іншій гіпотезі про генезу джерел варіювання урожайності сільськогосподарських культутур $[4,5,7]$.

Метою роботи $\epsilon$ розробити методичні підходи для виокремлення характеру дії на урожайність на регіональному масштабі факторів агроекологічної, агротехнологічної та агроекономічної природи.

Матеріали та методи. В основу дослідження покладено відкриті відомості про рівень урожайності зернових та зернобобових культур у середньому по адміністративним районам Полтавської області за період 1995-2016 рр. Відповідні відомості містяться в офіційних щорічних публікаціях «Сільське господарство Полтавської області» Головного управління статистики у Полтавській області (http://www.pl.ukrstat.gov.ua/).

Часові ряди урожайності по кожному адміністративному району були розбиті на дві компоненти: тренд та залишок тренду. Глобальний тренд був пояснений за допомого залежності урожайності культури від часу. В якості аналітичної форми тренду ми обирали між поліномами різного порядку. Надавали перевагу поліномам меншого порядку (більш простих за своєю аналітичною формою) та таким, які мають найбільшу пояснювальну здатність. Параметри лінійної моделі можуть бути самостійно інтерпретовані таким чином, що ним може бути наданий очевидний фізичний зміст. Це дозволяє відповідні коефіцієнти розглядати як самостійні змінні та досліджувати їх поведінку залежно від інших агроекологічних змінних, або досліджувати особливості їх просторової мінливості.

Просторова регулярність варіювання показників урожайності та параметрів тренду може бути досліджена за допомогою I-статистики Морана [9]. Розрахунки виконано у програмі GeoDa [13]. Географічну інформаційну систему побудовано за допомогою програми ArcGIS 10.2. Статистичні розрахунки виконано в програмі Statistica 10.0.

Результати та обговорення. Середній рівень та варіювання урожайності можуть бути порізному інтерпретовані як агроекологічні показники. Середній рівень врожайності $\epsilon$ маркером екологічного потенціалу регіону для продукування біомаси тієї або іншої культури. Варіювання урожайності вказує та стійкість агроекологічних систем як суперпозицію природних та агроекономічних чинників.

Аналіз одержаних даних свідчить про те, що врожайність культур зернових та зернобобових (у вазі після доробки) у сільськогосподарських підприємствах Полтавської області по районах у середньому за 1995-2016 рр. варіювала в межах від 29,79 2,79 ц/га (Кобеляцький район) до 41,10 $\pm 3,36$ ц/га (Шишацький район) (табл. 1).

Мінімальну врожайність встановлено у Козельщинському районі в 2000 р., а максимальну - у Гадяцькому райні в 2013 році. За період досліджень діапазон варіювання середньої врожайності становив від 35,40 ц/га (Диканьський район) до 61,00 ц/га (Чорнухинський район).

Коливання врожайності досліджуваних культур чітко відображають коефіцієнти варіації [12]. Найменший рівень варіювання показників врожайності культур зернових та зернобобових за період дослідження був характерний для Оржицького району (коефіцієнт варіації 27,95 \%), а найбільший - для Чорнухинського (CV =62,02 \%).

Географічно райони 3 високим та середнім рівенем врожайності соняшнику зосереджені на південному сході області - у Новосанжарському та Машівському районах. Також порівняно високі врожаї характерні для центральних районів Миргородського, Шишацького та Великобагачанського. Кластери с низькими средніми рівнями врожайності сформовані на півдні області (Козельщинський, Кобеляцький та Кременчуцький райони), на сході (Чутівський, Полтавський та Диканьський райони) та на заході (Гребінківський, Чорнухинський та Лубенський райони). 
СІЛЬСЬКЕ ГОСПОДАРСТВО. РОСЛИННИЦТВО

1. Урожсайність зернових та зернобобових культур (у вазі після доробки) у сільськогосподарських підприємствах Полтавської області по районах (u/2a, 1995-2016 рр.)

\begin{tabular}{|c|c|c|c|c|c|c|c|}
\hline \multirow{2}{*}{ № } & \multirow{2}{*}{ Район } & \multirow{2}{*}{ Середнє } & \multirow{2}{*}{ Мінімум } & \multirow{2}{*}{$\begin{array}{l}\text { Макси- } \\
\text { мум }\end{array}$} & \multicolumn{2}{|c|}{ Довірчий інтервал } & \multirow{2}{*}{$\mathrm{CV}, \%$} \\
\hline & & & & & $-95 \%$ & $+95 \%$ & \\
\hline 1 & Великобагачанський & $38,43 \pm 3,65$ & 20,10 & 74,80 & 20,10 & 74,80 & 44,53 \\
\hline 2 & Гадяцький & $36,74 \pm 4,39$ & 17,10 & 70,47 & 17,10 & 84,00 & 55,98 \\
\hline 3 & Глобинський & $35,44 \pm 2,58$ & 19,40 & 63,00 & 19,40 & 63,00 & 34,11 \\
\hline 4 & Гребінківський & $32,89 \pm 3,23$ & 17,70 & 74,50 & 17,70 & 74,50 & 51,23 \\
\hline 5 & Диканьський & $33,21 \pm 2,58$ & 18,50 & 53,90 & 18,50 & 53,90 & 36,39 \\
\hline 6 & Зіньківський & $33,74 \pm 3,01$ & 17,00 & 63,30 & 17,00 & 63,30 & 41,84 \\
\hline 7 & Карлівський & $35,96 \pm 3,09$ & 19,70 & 65,70 & 19,70 & 65,70 & 40,31 \\
\hline 8 & Кобеляцький & $29,79 \pm 2,79$ & 14,50 & 58,60 & 14,50 & 58,60 & 35,75 \\
\hline 9 & Козельщинський & $30,57 \pm 2,96$ & 13,40 & 71,09 & 13,40 & 59,50 & 39,65 \\
\hline 10 & Котелевський & $35,59 \pm 2,58$ & 19,20 & 67,71 & 19,20 & 60,00 & 34,01 \\
\hline 11 & Кременчуцький & $29,94 \pm 2,45$ & 14,20 & 54,70 & 14,20 & 54,70 & 38,33 \\
\hline 12 & Лохвицький & $37,40 \pm 4,44$ & 19,00 & 78,70 & 19,00 & 78,70 & 55,63 \\
\hline 13 & Лубенський & $32,92 \pm 3,44$ & 14,80 & 67,30 & 14,80 & 67,30 & 49,06 \\
\hline 14 & Машівський & $35,49 \pm 4,11$ & 16,10 & 72,70 & 16,10 & 72,70 & 39,27 \\
\hline 15 & Миргородський & $40,60 \pm 3,96$ & 18,90 & 73,10 & 18,90 & 73,10 & 45,79 \\
\hline 16 & Новосанжарський & $35,76 \pm 4,06$ & 15,90 & 76,50 & 15,90 & 76,50 & 42,99 \\
\hline 17 & Оржицький & $36,21 \pm 2,16$ & 19,59 & 62,90 & 24,90 & 62,90 & 27,95 \\
\hline 18 & Пирятинський & $35,11 \pm 3,46$ & 18,50 & 69,70 & 18,50 & 69,70 & 46,20 \\
\hline 19 & Полтавський & $32,97 \pm 2,63$ & 18,30 & 60,60 & 18,30 & 60,60 & 37,47 \\
\hline 20 & Решетилівський & $34,78 \pm 3,17$ & 19,40 & 80,25 & 19,40 & 66,00 & 42,73 \\
\hline 21 & Семенівський & $34,87 \pm 3,05$ & 16,80 & 61,50 & 16,80 & 61,50 & 41,05 \\
\hline 22 & Хорольський & $33,97 \pm 2,77$ & 18,00 & 71,00 & 18,00 & 71,00 & 38,25 \\
\hline 23 & Чорнухинський & $32,90 \pm 4,35$ & 14,30 & 75,30 & 14,30 & 75,30 & 62,02 \\
\hline 24 & Чутівський & $30,92 \pm 2,43$ & 17,40 & 53,40 & 17,40 & 53,40 & 36,86 \\
\hline 25 & Шишацький & $41,10 \pm 3,36$ & 22,90 & 71,90 & 22,90 & 71,90 & 38,35 \\
\hline
\end{tabular}
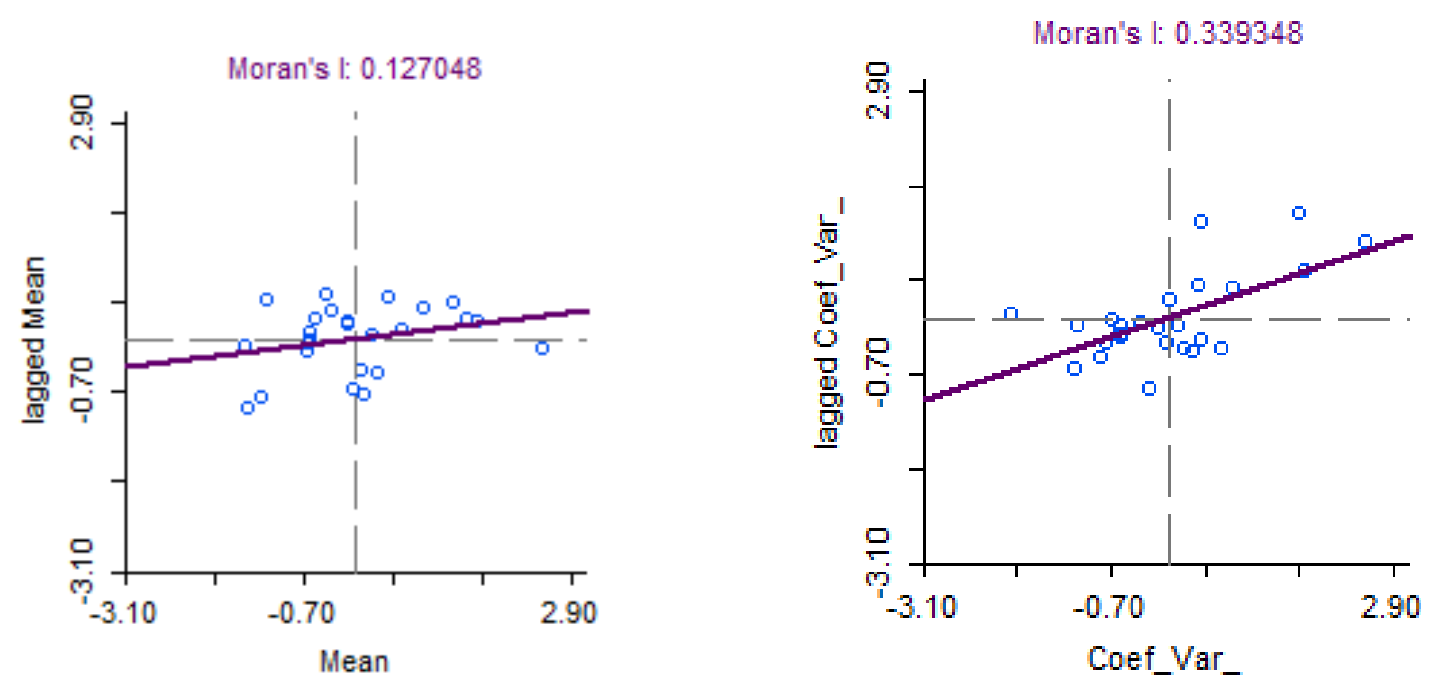

Рис. 1. Діаграма Морана для середнього рівня врожсайності зернових та зернобобових культур та коефіцієнту варіацї̈ цього показнику 


\section{СІЛЬСЬКЕ ГОСПОДАРСТВО. РОСЛИННИЦТВО}

Щодо варіабельності на півночі сформований чіткий кластер із районів 3 підвищеним рівнем варіювання врожайності зернових та зернобобових культур. До цього кластеру слід віднести Чорнухинський, Лохвицький та Гадяцький райони. Для сходу області характерні райони 3 низьким та середнім рівнем варіювання врожайності. Це Котелевський, Чутівський, Полтавський та Диканьський райони. Для деяких районів на заході також характерний низький рівень варіювання врожайності. Це Оржицький, Хорольський та Глобинський райони.

Оцінити значення просторової компоненти варіювання можна за допомогою діаграми Морана (рис. 1).

Міри просторової ваги обрані за ферзьподібною моделлю. Для середнього значення врожайності статистика I-Морана склала 0,13. Після 999 рандомізацій $p$-рівень відмінності від випадкової альтернативи склав 0,08. Таким чином, просторова компонента варіювання середнього рівня врожайності зернових та зернобобових культур незначна. Для коефіцієнту варіації врожайності статистика I-Морана склала 0,34, а
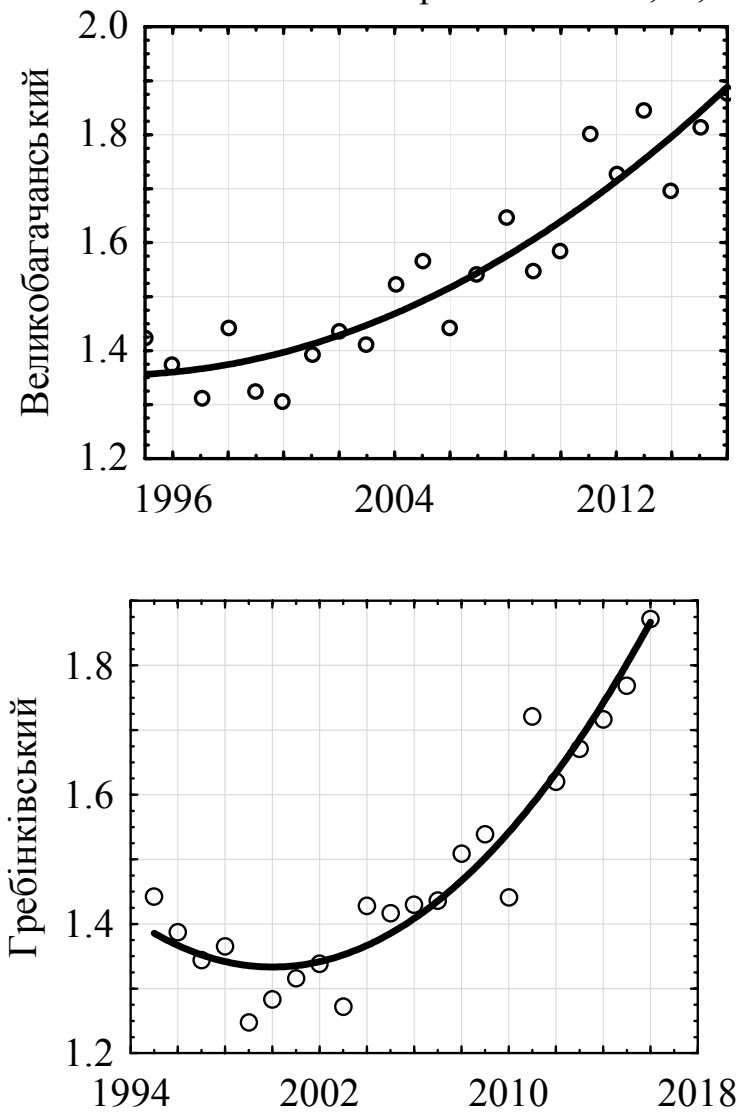

p-рівень після рандомізації склав 0,01, що вказує на суттєвий внесок факторів просторової природи у варіювання мінливості врожайності сільськогосподарських культур.

Аналіз динаміки урожайності зернових та зернобобових культур у сільськогосподарських підприємствах Полтавської області у часі вказує на наявність чіткого тренду збільшення врожайності за період дослідження. Додержання елементів технології вирощування сільськогосподарських культур, основними 3 яких $\epsilon$ живлення рослин та їх захист від шкідників, хвороб і бур'янів, забезпечили за цей період підвищення урожайності зернових та зернобобових культур [6]. У деяких районах загальний тренд збільшення $\epsilon$ монотонним (Великобагачанський, Глобинський, Диканьський та деякі інші) (рис. 2А). У деяких районах, яких більшість, періоду зростання передує період зниження, який припадає на середину 90-х років минулого століття (наприклад, Гребінківський, Лохвицький, Полтавський та деякі інші) (рис. 2B).
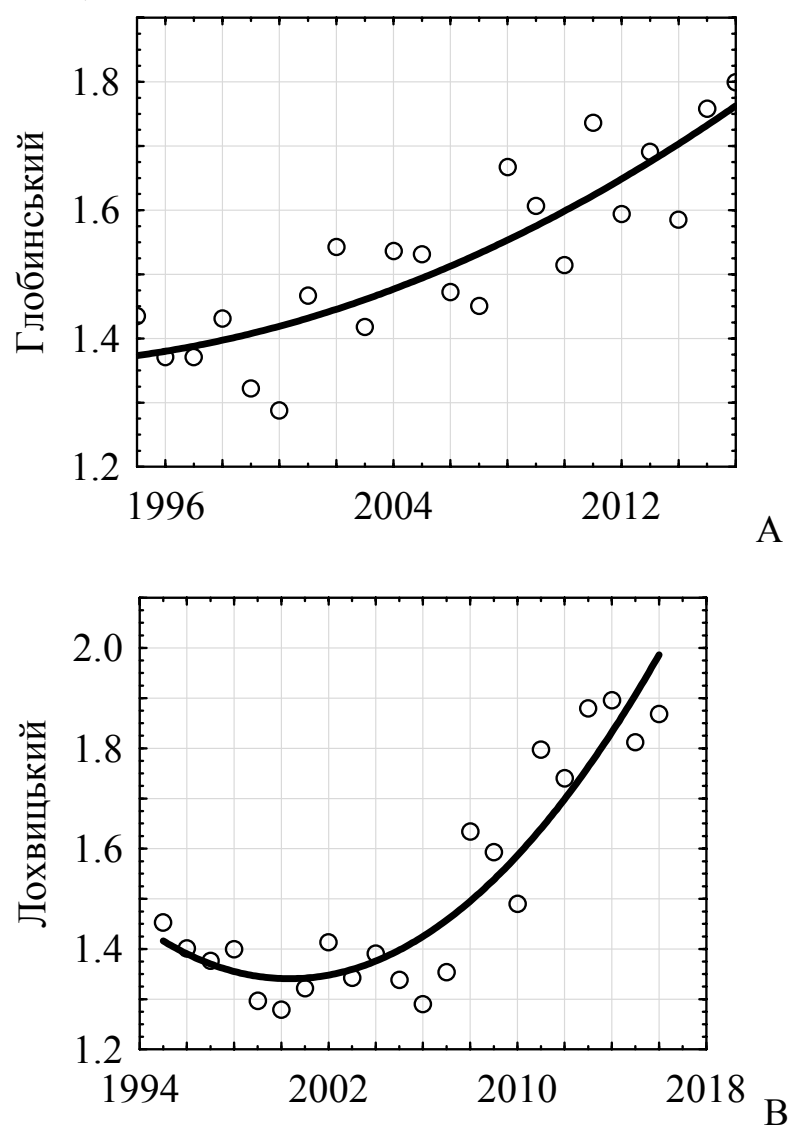

Рис. 2. Динаміка урожайності зернових та зернобобових культур (у вазі після доробки) у сільськогосподарських підприємствах Полтавськой області по районах (и/га, логарифмовані данні, 1995-2016 рр.)

Умовні позначки: А - типові райони з трендом без вираженого локального мінімуму; В - типові райони з трендом з локальним мінімумом 


\section{СІЛЬСЬКЕ ГОСПОДАРСТВО. РОСЛИННИЦТВО}

Наявність загального тренду по зростанню врожайності зернових та зернобобових культур дозволяє для аналітичного опису динаміки у часі застосувати лінійну модель виду:

$$
\mathrm{Y}=b x+a
$$

де $Y$ - врожайність у момент часу $x$, а $a$ та $b-$ коефіцієнти. Слід відзначити, що ці коефіцієнти можна змістовно інтерпретувати. Коефіцієнт $b$ можна інтерпретувати як швидкість зростання урожайності 3 часом, а $a-$ як потенціал урожайності у початковий період дослідження. Зауважемо, що коефіцієнти розраховуються за методом найменших квадратів та в розрахунку приймають участь усі експериментальні данні. Таким чином, як швидкість зростання, так i потенціал на початку спостережень розраховані певною мірою ретроспективно.

Наявність локального мінімуму та відхилення від лінійного характеру залежності навіть логарифмованих даних робить більш коректною модель другого порядку виду:

$\mathrm{Y}=k \cdot x^{2}+b \cdot x+a$,

де $k \cdot$ - коефіцієнт біля нелінійного члену моделі $x^{2}$. Інтерпретувати відповідні коефіцієнти більш складно. Знак коефіцієнту $k$ вказує на наявність локального максимуму (від'ємні значення коефіцієнту) або локального мінімуму (позитивне значення коефіцієнту). Локальний мінімум як правило спостерігається у дослідженому часовому діапазоні. Тоді як локальний максимум виходить за межі дослідженого часового діапазону. Це свідчить про те, що у такому випадку рівняння другого порядку може бути не коректним для описання залежності урожайності від часу, а більш прийнятним буде інша аналітична форма. Також коефіцієнт $a$ вказує на значення нелінійної компоненти варіювання ознаки. Якщо він наближається до нуля, то рівняння перетворюється у рівняння першого порядку.

Вільний член аналогічно лінійній залежності вказує на потенціал урожайності культур на початку періоду досліджень. Кількісно цей коефіцієнт буде більшим порівняно 3 лінійною моделлю у разі наявності локального мінімуму або меншим при наявності локального максимуму. В цілому, нелінійна модель більш точно здатна оцінити цей показник.

Коефіцієнт $b$ вказує на лінійну компоненту варіювання ознаки, а також від нього залежить місцезнаходження по осі абсцис локального екстремуму. Але це положення залежить також і від коефіцієнту $k$. Таким чином, аналітичну функцію краще виконує лінійна залежність, а описову поліном другого ступеню.

Аналіз просторового варіювання коефіцієнту $a$ лінійної моделі вказує на те, що найменший потенціал врожайності на початок періоду досліджень був відмічений для Чорнухинського району та районів, які до нього наближені (Лохвицький, Лубенський, Пирятинський, Гадяцький, Гребінківський) (рис. 3).

Також малий потенціал врожайності характерний для південних районів - Козельщинського та Кобеляцького. Райони 3 найбільшим потенціалом урожайності зернових та зернобобових протягом 1995-2016 рр. розміщені дифузно. На заході це Оржицький район, у центрі - Шишацький, на сході - Котелевський та Карлівський райони.

Між коефіцієнтами $a$ та $b$ встановлена статистично вірогідний кореляційний зв'язок $(r=-0,72$, $p=0,00)$. Це дещо пояснює ту обставину, що карта коефіцієнту $b \in$ певною мірою негативом карти коефіцієнту $a$. Так, низький потенціал врожайності на початку періоду дослідження в Чорнухинському районі компенсований значною швидкістю зростання врожайності за увесь період. Відповідно, для північних районів у цілому характерні високі темпи зростання урожайності зернових та зернобобових протягом 1995-2016 рр. Навпаки, на сході, заході та півдні встановлені осередки низьких темпів нарощування врожайності.

Коефіцієнт детермінації вказує на рівень відповідності спостережуваних даних запропонованій моделі. Залишок коефіцієнту детермінації до одиниці вказує на значення інших, ніж загальний лінійний тренд, причин варіювання ознаки, або випадкових причин (помилки). Найбільш добрі результати дає лінійна модель для центральних (Миргородський, Великобагачанський) та південно-східних (Новосанжарський) районів (рис. 4). Найнижчі значення коефіцієнту детермінації характерні для сходу (Чутівський район), заходу (Оржицький район) та південного заходу (Кременчуцький та Козельщинський райони).

Параметри лінійної моделі тренду врожайності зернових та зернобобових культур характеризуються наявністю певного рівня просторової компоненти своєї мінливості. Статистика I-Морана для коефіцієнту $а$ становить 0,12. Після процедури рандомізації встановлений $p$-рівень вірогідності відмінності від випадкової альтернативи 0,08. Для коефіцієнту $b$ статистика $I$-Морана становить 0,25 ( $p$-рівень 0,02), а для коефіцієнту детермінації $R 2-$ 0,21 ( $p$-рівень 0,03). Таким чином, потенціал урожайності зернових та зернобобових культур на початку періоду досліджень характеризується найменшим рівнем просторової залежності, тоді як у варіюванні швидкості зростання врожайності та для коефіцієнту детермінації просторова компонента є дуже важливою. 


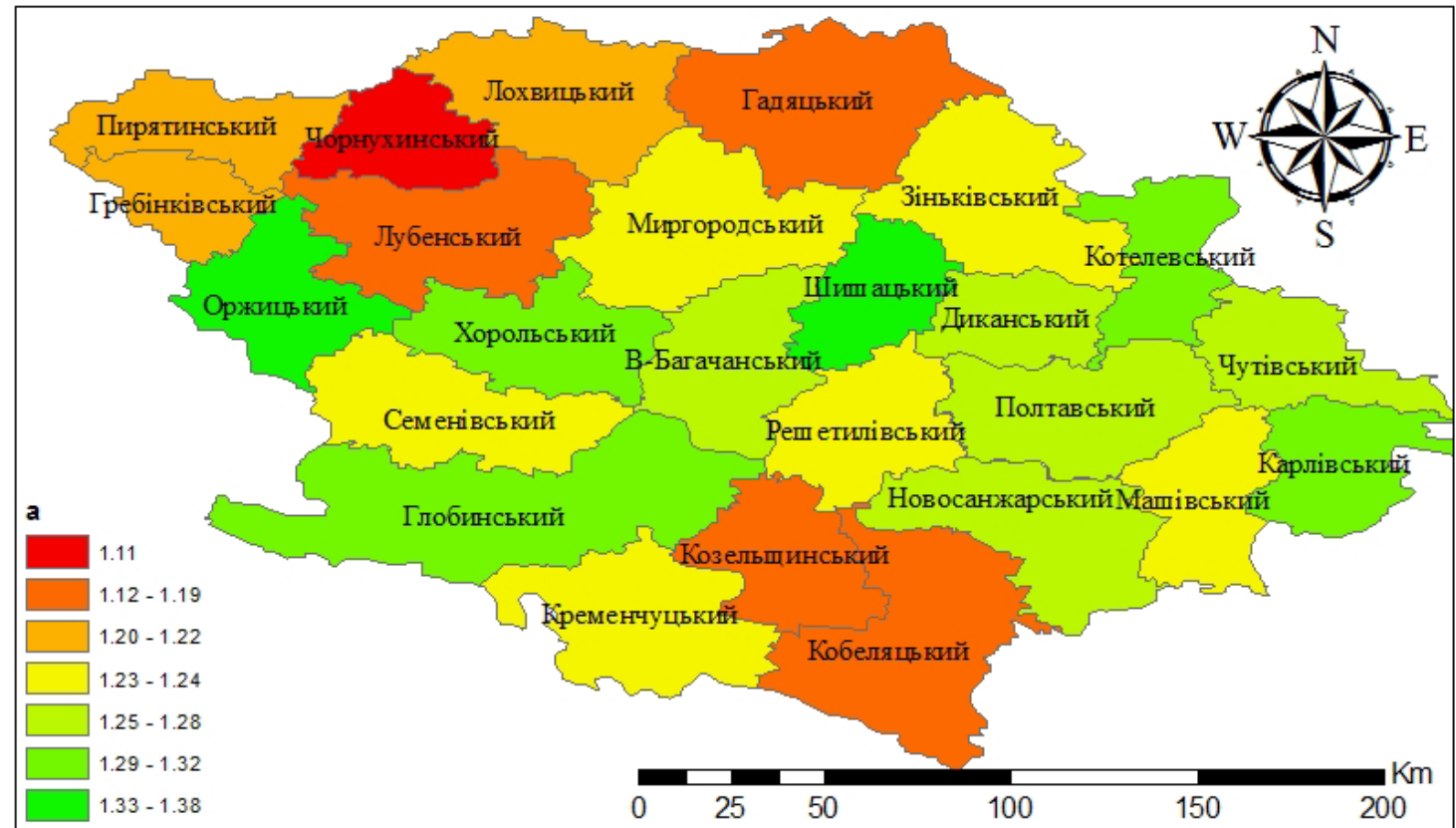

$\boldsymbol{A}$

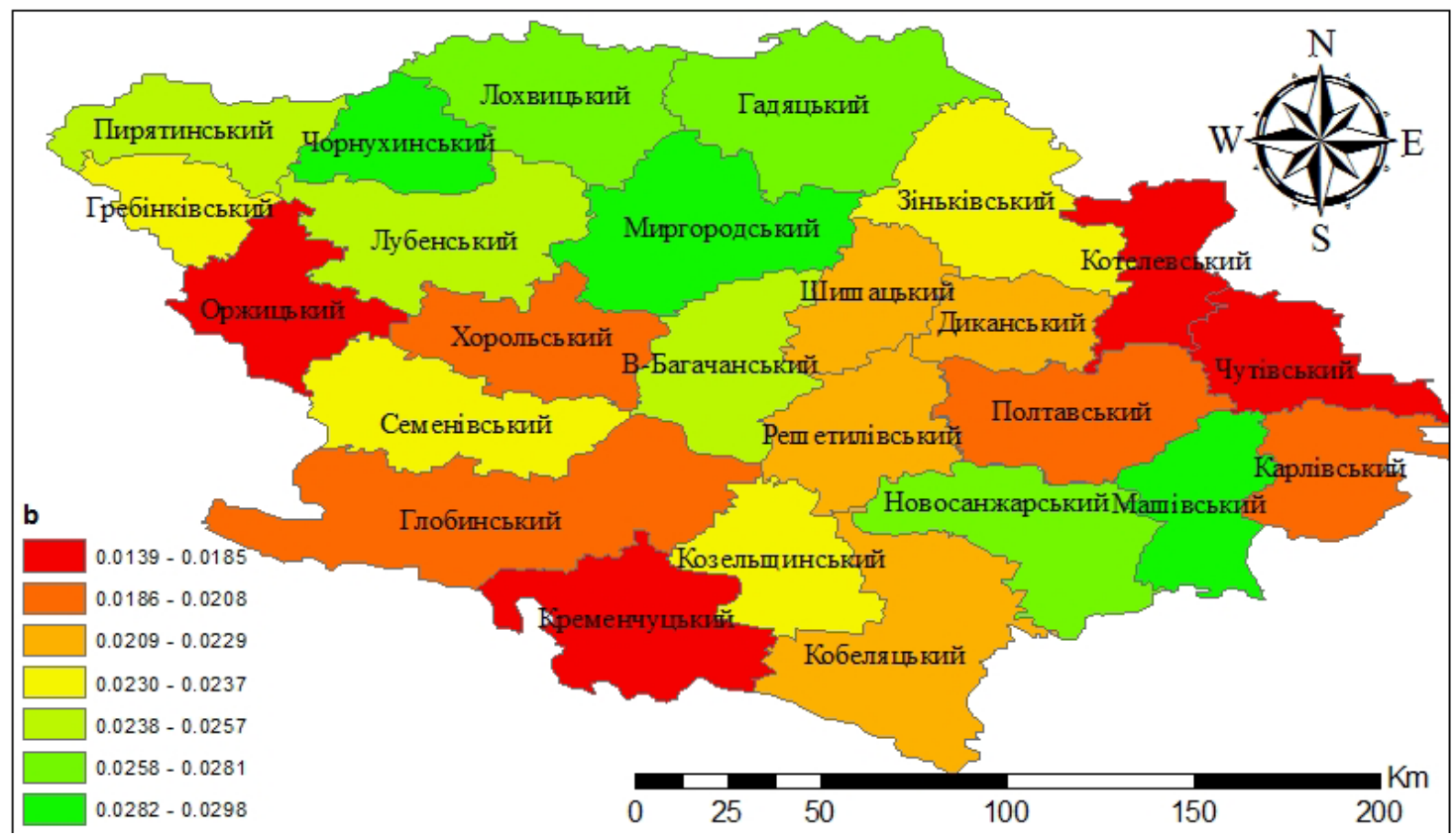

$\boldsymbol{B}$

Рис. 3. Просторове варіювання параметрів лінійної регресії тренду урожайності культур зернових та зернобобових за період 1995-2016 pp.

А: коефіцієнт а-потенціал врожайності на початок періоду, В: коефіцієнт b- ивидкість зростання

Очевидно, що зростання врожайності сільськогосподарських культур, яке має характер стійкого тренду протягом значного періоду часу, в своїй основі має агроекономічні чинники. Але просторово обумовлені відхилення від загального тренду мають агроекологічну природу внаслі- док територіальної єдності екологічних причин, які не прив'язані до адміністративного членування території регіону. Таким чином ми бачимо, що результативність агроекономічних зусиль значною мірою залежить від агроекологічних обставин. 


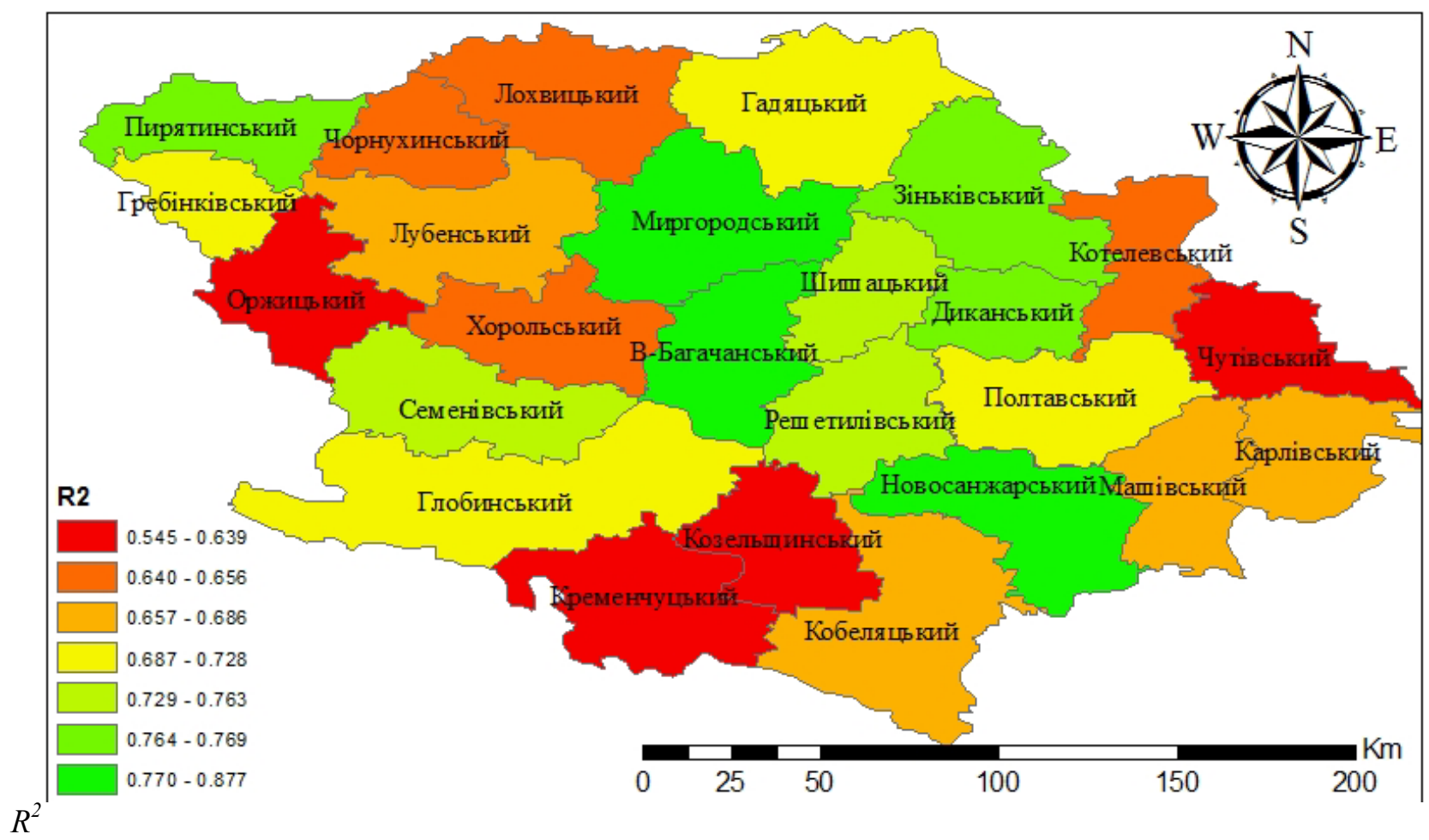

\section{Рис. 4. Просторове варіювання коефіцієнту детермінації лінійної регресії тренду урожсайності зернових та зернобобових культур протягом 1995-2016 рр.}

\section{Висновки:}

1. Врожайність культур зернових та зернобобових (у вазі після доробки) у сільськогосподарських підприємствах Полтавської області по районах у середньому за 19952016 рр. варіювала в межах від 29,79 $\pm 2,79$ ц/га (Кобеляцький район) до $41,10 \pm 3,36$ ц/га (Шишацький район). Найменший рівень варіювання показників врожайності культур зернових та зернобобових за період дослідження був характерний для Оржицького району (коефіцієнт варіації 27,95 \%), а найбільший - для Чорнухинського $(\mathrm{CV}=62,02 \%)$.

\section{БІБЛІОГРАФІЯ}

1. Бабич В. А. Планирование орошения с помощью информационно-вычислительных систем: автореф. дис. ... к. т. н.: спец. 06.01.02 / В.А. Бабич.; Укр. НИИ гидротехники и мелиорации. - К., 1992. - 21 с.

2. Витлинский В. В. Полигармоническое прогнозирование как метод минимизации инвестиционных рисков в зернопроизводстве / В.В. Витлинский, П.М. Грицюк // Тр. Межд. научн. конф. «Моделирование и анализ безопасности и риска». - СПб.: ГУАП, 2008. - С. 231-236.

3. Гринчук T. Підходи до аналізу сучасного стану зерновиробництва у сільськогосподар-
2. Просторова компонента варіювання середнього рівня врожайності зернових та зернобобових культур незначна. Встановлено суттєвий внесок факторів просторової природи у варіювання мінливості врожайності сільськогосподарських культур.

3. Встановлено чіткий тренд збільшення врожайності зернових та зернобобових за період дослідження, який може бути описаний лінійною залежністю. Коефіцієнти лінійної моделі змістовно інтерпретовані як швидкість зростання урожайності 3 часом та потенціал урожайності у початковий період дослідження.

ських підприємствах регіону та факторів, які впливають на його розвиток / Т. Гринчук // Науковий вісник [Одеського національного економічного університету]. - 2015. - № 9. C. $48-60$.

4. Демидов А. А. Пространственная агроэкология и рекультивация земель: монография / А.А. Демидов, А.С. Кобец, Ю.И. Грицан, А.В. Жуков. - Днепропетровск: Изд-во «Свидлер А.Л.», 2013. - 560 с. DOI: 10.13140/ RG.2.1.5175.5040

5. Диченко О. Ю. Просторова агроекологія як основа прогнозу чисельності шкідників / 
О. Ю. Диченко, П.В.Писаренко, О.М.Кунах, О. В. Жуков. Навчальний посібник. - Дніпропетровськ: ДНУ, 2015. - 139 с. DOI: 10.13140/ RG.2.1.1014.4485

6. Доронін А. В. Сучасний стан зернового ринку в Україні / А.В. Доронін // Наукові праці Інституту біоенергетичних культур і цукрових буряків. - 2014. - Вип. 21. - С. 270-276.

7. Жуков О.В. Роль ландшафтного різноманіття у динаміці чисельності популяцій шкідників цукрового буряку в Полтавській області / О. В. Жуков, П. В. Писаренко, О. М. Кунах, О. Ю. Диченко // Вісник Дніпропетровського університету. Біологія. Екологія. - 2015. - Вип. 23, т. 1. - С. 21-27.

8. Жуков О.В. Оцінка варіювання у просторі та часі рослинного покриву засобами дистанційного зондування Землі / О. В. Жуков, П. В. Писаренко, О. М. Кунах, О. Ю. Диченко // Вісник Дніпропетровського державного аграрноекономічного університету. - 2015. - №2 (36). C. $105-112$.
9. Жуков О. В. Аналіз просторових даних в екології та сільському господарстві / О. В. Жуков. - Дніпропетровськ: ДНУ, 2015. 124 c. DOI: $10.13140 /$ RG.2.1.3480.2406

10. Жуков О. В. Екологія техноземів: монографія / О.В. Жуков, Г.О. Задорожна, К. П. Маслікова, К.В. Андрусевич, І.В. Лядська - Дніпро: Журфонд. - 2017. - 442 с.

11. Кобеиь А. С. Агроекологічні перспективи розвитку природного агровиробництва / А. С. Кобець, М. М. Харитонов, Ю. І. Грицан, О. В. Жуков // Вісник Дніпропетровського державного аграрно-економічного університету. 2015. - №4 (38). - С. 6-10.

12. Орленко О. В. Дослідження динаміки врожайності круп'яних культур 3 використанням кореляційно-регресійного моделювання / О.В. Орленко // Глобальні та національні проблеми економіки. - 2015. - Вип. 7. - С. 574-576.

13. Anselin L. GeoDa: An Introduction to Spatial Data Analysis // L. Anselin, S. Ibnu, Kh. Youngihn / Geographical Analysis. - 2006. - Vol. 38 (1). - P. 5-22. 